\title{
Evaluation and utilization of the Hevea germplasm collected from 1981 IRRDB expedition to the Amazon; a review
}

\author{
S P Withanage*, D P S T G Attanayake** N E M Jayasekara*, K K Liyanage*, \\ K B Karunasekara* and I D M J Sarath Kumara* \\ * Rubber Research Institute of Sri Lanka, Dartonfield, Agalawatta, Sri Lanka \\ ** Faculty of Agriculture and Plantation Management, Wayamba University of Sri Lanka, \\ Makandura, Gonawila, Sri Lanka
}

\begin{abstract}
Rubber industry in Sri Lanka that extends approximately around 133,000 ha, is largely based on Wickham's genetic base. Use of genetically improved high yielding planting materials is perhaps the only and cheapest way to increase the yield per unit area. However, due to directional selection carried during past Hevea breeding, the genetic diversity in the Hevea breeding pool has started to narrow down. Non Wickham's genetic collections can provide genetic diversity and possible desirable genes for plant breeders to overcome this situation. Currently around 8000 accessions of Hevea germplasm have been collected and conserved in Sri Lanka. Majority of them came from the collection of 1981 International Rubber Research Development Board expedition in the Amazonian habitats. The characterization and evaluation of this germplasm was started in early 1990's and continue until today. Two direct selections to the RRISL clone recommendation has been made in 1994 as GPS I and GPS II. Large number of accessions were used in nearly nine hand pollination programmes carried since 1995 and resulted in development of around 1075 new genotypes which now in various evaluation steps. Ten selected genotypes from 1995 hand pollination programme are now in the advanced stage of evaluation, before the recommendation. The process of characterization, evaluation and maintenance of ex-situ germplasm collection with a wide range of genetic materials for useful trials is in progress.
\end{abstract}

Key words: breeding, genetic diversity germplasm, Hevea

Rubber (Hevea brasiliensis) is the $3^{\text {rd }}$ largest plantation crop in Sri Lanka next to the tea and coconut. The total extent of cultivated rubber has been estimated to be around 133,000 ha (Anon 2012) and the rubber industry provides employment, both directly and indirectly to about 500,000 persons (Anon 2012). Nearly $65 \%$ of the rubber is owned by smallholders and majority 
of them fall into low income groups. The only way to increase this low income is by increasing the yield per unit area of land. Use of genetically improved high yielding planting material is perhaps the only and also the easiest way to achieve this. Thus a sound, efficient and result oriented Hevea breeding programme is vital to the survival of rubber industry in Sri Lanka especially in the face of increasing cost of production.

For several years, Geneticists and Plant Breeders have emphasized the need to conserve Hevea genetic resources and to widen the genetic base of breeding populations used by the natural rubber producing countries. Rubber breeding in Sri Lanka is largely based on a small population of about 1919 seedlings introduced in 1876 from Wickham collection. It is believed that Sri Lanka was the centre of distribution of rubber plants to other South East Asian (SEA) countries. Further, introduction of new material from natural habitats has been restricted due to the fear of accidental introduction of South American Leaf Blight (SALB) to this region. Therefore, genetic base in the original population is narrow.

Directional selection during last 80 years of breeding for few economically important characters such as yield, vigor and disease tolerance and also extensive use of clonal vegetative propagation has led to further erosion of genetic variability. Consequently, problems related to breeding and selection of Hevea, such as inbreeding depression which lead to declining yield response are becoming more apparent.

Most Hevea breeders believe that they have exploited the maximum genetic variability of Wickham's original introduction and have reached the threshold point with respect to economically important characters such as yield and vigor. Hevea breeders felt the need for exploration, collection and conservation and use of Hevea genetic material to widen the genetic base of present breeding populations. Necessity for such action becomes even more important as natural stands of Hevea in Amazon region are endangered by extensive felling of jungle land for agricultural purposes.

\section{Expedition to collect wild Hevea germplasm}

In 1981 member countries of the International Rubber Research and Development Board (IRRDB) funded a project to collect new Hevea germplasm. The first discussion on the importation of wild Hevea germplasm, was held at the Colombo meeting of IRRDB in 1976. Following these, the basic preparations for the proposal of IRRDB project "Collection and conservation of Hevea planting materials from south America" were arranged at IRRDB "Plant Breeders" workshop at Kuala Lampur, Malaysia in 1977. Then in 1978, a preliminary mission was done in various South American countries such as Bolivia, Brazil Colombia, Guyana, French, Guiana, Venezuela and Thailand with the aim to arrange scientists and governmental support and contacts. The 
collection team consisted of eight scientists from Malaysia, Thailand, Indonesia, the Peoples' Republic of Code d'Ivory (Ivory Coast) and Nigeria. Three scientists also joined from Brazil.

This collection is now maintained in The Peoples' Republic of Code d'Ivory and Malaysia which serve as distribution centers for African and Asian member countries of IRRDB. Rubber Research Institute of Sri Lanka (RRISL) has spent more than US \$ 87,500 for the collection and maintenance of these materials at the Rubber Research Institute of Malaysia (RRIM). Sri Lanka has received about 10,000 genotypes from the RRIM and some of genotypes maintain in the African centre too.

\section{Location of expedition}

Three main areas were selected in the Western state of Brazil (Table 1), namely,

1. Acre - better quality rubber, Vigorous and high yielding

2. Rondonia - vigorous and high yielding, variation in the species Hevea brasiliensis

3. Mato Grosso - variation in the species Hevea brasiliensis

Sample collected trees were very old and their girth ranged from $3 m-6 m$ at $1 \frac{1}{2} \mathrm{~m}$ height from the ground. Also these trees had been already subjected to tapping by native tappers using a multiple cutting system. It showed large volumes of latex around $1 \frac{1}{2} \mathrm{~L}$ to $4 \mathrm{~L}$ per tapping.

Table 1. Exploited locations based on districts and states

\begin{tabular}{llc}
\hline States & Districts & Number of location \\
\hline Acre & Brasileia & 6 \\
& Feijo & 4 \\
& Sena Madureira & 6 \\
& Tarauaca & 4 \\
Mato Grosso & Xapuri & 2 \\
& Aracotuba & 5 \\
& Cartriquacu & 11 \\
Rondonia & Itauba & 7 \\
& Vila Bela & 1 \\
& Ariquemes & 1 \\
& Calama & 2 \\
& Costa Marques & 3 \\
& Jaru & 2 \\
& Jiparana & 1 \\
& Ouro Preto & 1 \\
\hline
\end{tabular}

Germplasm code: eg AC/ B/1-5: (Acre state/ Brasileia district/ Location number 01- $05^{\text {th }}$ Accession or genotype) 
The expedition group collected a total 64,736 seeds and $1522 \mathrm{~m}$ of bud wood from 194 presumably high yielding mother trees.

\section{Dispatch of germplasm}

This collection was first dispatched to the National Centre of Rubber and Oil Palm Research in Brazil in Manaus (CNPSD) and subjected to a whole procedure of very strong phytosanitary measures (Fig. 1).

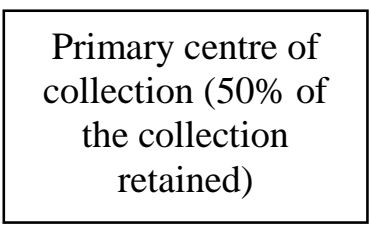

Collected from: Acre, Mato Grosso and Rondonia State $50 \%$ of the collection Brazil in Manaus (CNPSD)

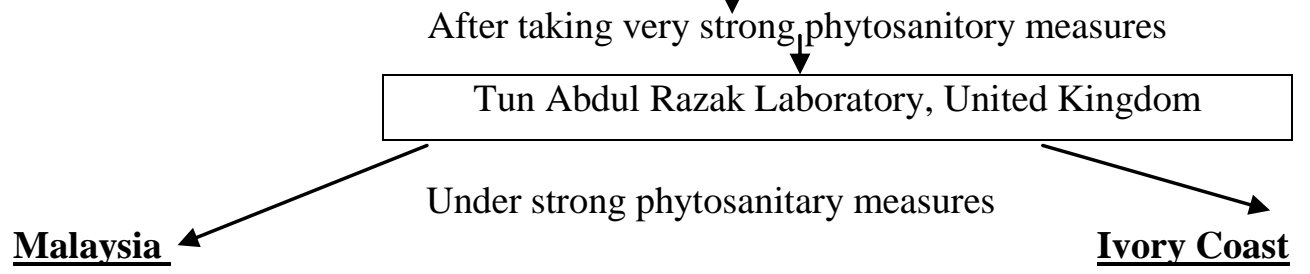

RRIM Head Quarters KL

(20,030 seeds)

Isolated seed beds

Strong phytosanitory measures

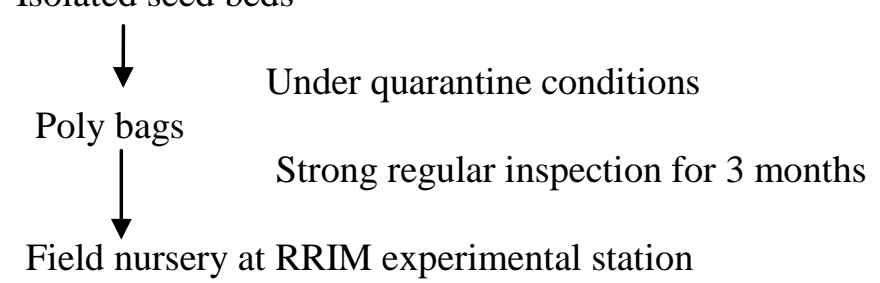

Field nursery at RRIM experimental station $(14,316$ seeds $)$

Established source bush nursery (Around 10,000 germplasm collection)

South East Asia Countries - Sri Lanka - Received around 8000 genotypes during the period of 1986-1987

Fig. 1. Dispatch Procedure of germlasm collected from: Acre, Mato Grosso and Rondonia States
Under supervision of Common Wealth Mycological Institute Kew UK

Followed similar process as in Malaysia

Around 3000 collection

IRRDB member countries in Africa 
Establishment and attempts taken to evaluate and utilize the Hevea germplasm in Sri Lanka

Sri Lanka received its first consignment of 100 germplam clones in 1984 and further 8564 genotypes, periodically during the period of 1985-1989. This ex-situ collection of non-Wickham germplasm was established at Dickhena division, Neuchatle estate plantation, Kalutara district, in an area around 13.5 ha. From each genotype four plants were multiplied and planted in close $(1 \mathrm{~m} \mathrm{X} \mathrm{1m).}$

\section{Evaluation of first consignment of 100 germplasm clones at Kuruwita Sub station for direct selections}

First consignment of 100 germplasm clones was established at Kuruwita substation under small scale level and Morris - Man test tapping was started at the end of year 1989 (Jayasekara, 1989). Five girth measurements recorded from 1988 to 1992 , inclusive of both years, were used to work out the growth rates by regressing individual tree girth on two years taking years $1,2,3,4$ and 5 as independent variable (Jayasekara, 1991).

Analysis of variance performed on growth rates of individual trees indicated highly significant differences between clones and between classes, when clones were classified according to their origin, indicating differences in growth rates of clones of different origins. Duncan Multiple Range Test carried out resulted in 17 groups with considerable overlapping. This made it extremely difficult to group them according to their vigour.

In group $a$, with a highest mean girth of $8.52 \mathrm{~cm}$ all 3 clones with Wickham origin were included.

There were germplasm clones that had higher growth rates than some of the Wickham derivatives such as RRIC 102 and RRIM 600. RRIC 121 had the highest mean $(9.940 \mathrm{~cm})$ followed by a germplasm clone MT-C-1 -1 with a mean girth of $9.45 \mathrm{~cm}$. This indicated that germplasm clones could be a good resource material to incorporate new genetic variability with respect to vigour (Jayasekara, 1992). In addition to the study of the latex vessel rings of bark samples collected from this trial, test tapping was carried out (Jayasekara, 1993).

Other than above evaluation, around 300 plants in this nursery with a girth of $60 \mathrm{~cm}$ and above were marked at $90 \mathrm{~cm}$ above the bud union for test tapping, the clones that did not give promising yields were discontinued and another batch of 300 plants that had reached the required girth of $60 \mathrm{~cm}$ and above were brought into tapping. This second batch and the promising clones selected from the first batch were test tapped to evaluate the yield potential.

Two highly promising clones which yield more than $100 \mathrm{~g} / \mathrm{t} / \mathrm{t}$ have been identified for future testing in large scale trials (Jayasekara, 1993).

The two promising genotypes that were identified in 1993 were test tapped in 1994.Yield of one genotype (GPS II) dropped while the other genotype (GPS 
1) continued to give high yields. Mean yield of these two genotypes and the number of test tappings done in 1994 are shown in Table 2 (Jayasekara, 1994).

Test tapping of plants, led to identification of four genotypes which can yield more than $30 \mathrm{~g}$ per tree per tapping. Test tapping yield, both average over first three years and the fourth year average are given in Table 3 (Jayasekara, 1994).
Utilization of germplasm in breeding programs in Sri Lanka during 1995-

\section{4}

This $e x$-situ collection has been used in hybridization programmers frequently from year 1995 onwards aiming to improve the genetic diversity of rubber plantations in Sri Lanka. These progenies are now being evaluated in various steps successfully (Table 4).

Table 2. Two promising genotypes selected from evaluation of first consignment of 100 germplasm clones at Kuruwita sub station

\begin{tabular}{lcc}
\hline Clone/germplasm code & Yield $(\mathbf{g} / \mathbf{t} / \mathbf{t})$ & No. of test tapping \\
\hline GPS 1 (AC/S/12-559) & 91.7 & 40 \\
GPS II (AC/F/6A-471) & 40.2 & 36 \\
\hline
\end{tabular}

Table 3. Four promising genotypes yielded more than $30 \mathrm{~g}$ per tree per tapping, selected from evaluation of first consignment of 100 germplasm clones with at Kuruwita sub station

\begin{tabular}{lcc}
\hline Clone/germplasm code & $\begin{array}{c}\text { Average yield (g/t/t) for } \\
\text { first 3 years* } \\
\text { (1992 to 1994) }\end{array}$ & $\begin{array}{c}\text { Average yield (g/t/t) the forth } \\
\text { year** }\end{array}$ \\
\hline 22-137 (RO/JP/3-137) & $41.65(77)$ & $33.41(156)$ \\
GPS II (AC/F/6A -471) & $46.36(73)$ & $42.72(151)$ \\
GPS 1 (AC/S/12-559) & $77.65(73)$ & $99.85(156)$ \\
44-24 (RO/CM/10-24) & $48.01(77)$ & $46.83(153)$ \\
\hline
\end{tabular}

*In parenthesis indicates the number of test tapping on which the average yield is based. 
Table 4. Use of germplasm clones in hybridization programme during 1995-2014 and performance of their progenies

\begin{tabular}{|c|c|c|c|c|c|}
\hline $\begin{array}{l}\text { HP } \\
\text { year }\end{array}$ & $\begin{array}{l}\text { Clone/germ } \\
\text { plasm code } \\
\text { of female } \\
\text { parent }\end{array}$ & $\begin{array}{l}\text { Germplasm code of } \\
\text { male parent }\end{array}$ & $\begin{array}{r}\text { No. of } \\
\text { new } \\
\text { genotypes } \\
\text { produced }\end{array}$ & \multicolumn{2}{|c|}{$\begin{array}{l}\text { Evaluation stage/ } \\
\text { performances of new } \\
\text { genotypes }\end{array}$} \\
\hline 1995 & RRIC 100 & (GPS 1) AC/.S/12-559 & 42 & \multicolumn{2}{|c|}{$\begin{array}{l}\text { Selected HP entries } 95-33 \text { and } \\
\text { now at RRI/ECTs* evaluation. } \\
\text { However, this selection was } \\
\text { grouped with some of } \\
\text { recommended clones (Fig. 3) } \\
\text { and evaluate (RRI/ECT) } \\
\text { collaborative trial 2011- } \\
\text { Yatadola }\end{array}$} \\
\hline 1996 & RRIC 121 & GPS $1 / \mathrm{AC} / . \mathrm{S} / 12-559$ & 46 & \multicolumn{2}{|c|}{$\begin{array}{l}\text { Four HP entries (96-58, } 96-14 \text {, } \\
96-8 \text { and } 96-15) \text { performed } \\
\text { well above the control clone } \\
\text { RRIC } 121 \text { and taken to } \\
\text { RRI/ECTs *evaluation }\end{array}$} \\
\hline 2000 & $\mathrm{BPM}-24$ & (GPS $36-104)$ & 19 & \multirow{2}{*}{\multicolumn{2}{|c|}{ Small Scale Clone trials }} \\
\hline & RRIC 121 & $\mathrm{AC} / \mathrm{F} / 6 \mathrm{~A}-104$ & 48 & & \\
\hline 2001 & RRIC 100 & GPS 1/AC/.S/12-559 & 15 & \multicolumn{2}{|c|}{ Small Scale Clone trials } \\
\hline 2002 & $\begin{array}{l}\text { IAN 48/875 } \\
\text { RRISL 2001 } \\
\text { PB } 261\end{array}$ & GPS $1 / \mathrm{AC} / . \mathrm{S} / 12-559$ & $\begin{array}{l}11 \\
02 \\
01\end{array}$ & \multicolumn{2}{|c|}{ Small Scale Clone trials } \\
\hline 2007 & RRIC 130 & & & \multicolumn{2}{|c|}{$\begin{array}{l}\text { Small Scale Clone trials - } \\
\text { According to sixth year girth } \\
\text { data, the progeny RRIC } 130 \mathrm{X} \\
\text { GP } 1-2 \text { showed significantly } \\
\text { higher girth value. }\end{array}$} \\
\hline & & $(\mathrm{GPS} 1-2) 07.02 .81-02$ & 29 & \multirow{5}{*}{$\begin{array}{l}\text { Mean girth at } \\
5^{\text {th }} \text { year }\end{array}$} & $61.5 \mathrm{a}$ \\
\hline & & $\begin{array}{l}(\mathrm{GPS} 44-24) \\
\mathrm{RO} / / \mathrm{CM} / 10-24\end{array}$ & 1 & & $52^{a b^{-\cdots}}$ \\
\hline & & $\begin{array}{l}\text { (GPS 22-137) } \\
\text { RO/JP/03-137 }\end{array}$ & 262 & & $50.9^{\mathrm{ab}}$ \\
\hline & & $\begin{array}{l}\text { (GPS 21-163) } \\
\text { AC/F/05-163 }\end{array}$ & 124 & & $49.98^{\mathrm{ab}}$ \\
\hline & & $\begin{array}{l}(\mathrm{GPS} 10-154) \\
\mathrm{MT} / \mathrm{C} / 02-154)\end{array}$ & & & $41.17^{6-1}$ \\
\hline
\end{tabular}




\begin{tabular}{|c|c|c|c|c|}
\hline $\begin{array}{l}\text { HP } \\
\text { year }\end{array}$ & $\begin{array}{l}\text { Clone/germ } \\
\text { plasm code } \\
\text { of female } \\
\text { parent }\end{array}$ & $\begin{array}{l}\text { Germplasm code of } \\
\text { male parent }\end{array}$ & $\begin{array}{r}\text { No. of } \\
\text { new } \\
\text { genotypes } \\
\text { produced }\end{array}$ & $\begin{array}{l}\text { Evaluation } \\
\text { stage/performances of new } \\
\text { genotypes }\end{array}$ \\
\hline 2008 & $\begin{array}{l}\text { PB } 28-59 \\
\text { RRIC } 121 \\
\text { RRIC } 100\end{array}$ & $\begin{array}{l}\text { (GPS } 36-147 \text { ) } \\
\text { AC/F/6A-147 } \\
\text { GPS } 21-163 \\
\text { GPS } 22-373 \\
\text { GPS } 1-4 \\
\text { GPS } 36-160 \\
\text { IAN } 45 / 873 \\
\text { GPS } 1-47 \\
\text { GPS } 22-271\end{array}$ & $\begin{array}{r}27 \\
48 \\
39 \\
4 \\
2 \\
27 \\
4 \\
5\end{array}$ & $\begin{array}{l}\text { Small Scale Clone trials - } \\
\text { Higher elevation }\end{array}$ \\
\hline 2012 & $\begin{array}{l}\text { RRISL } 2005 \\
\text { RRISL } 2006 \\
\text { Hevea nitida }\end{array}$ & $\begin{array}{ll}\text { GPS } & 22-16 \\
\text { GPS } & 22-493 \\
\text { GPS } & 22-4 \\
\text { GPS } & 11-76 \\
\text { GPS } & 22-500 \\
\text { GPS } & 22-137 \\
\text { IAN } & 45 / 710\end{array}$ & $\begin{array}{l}26 \\
41 \\
41 \\
06 \\
15 \\
16 \\
09\end{array}$ & $\begin{array}{l}\text { Established at mother plant } \\
\text { nursery } \\
\text { Genetic diversity analysis of } \\
\text { selected parental materials } \\
\text { were completed by using } \\
\text { RAPD markers (Fig.3). } \\
\text { Selected female parents of } \\
\text { RRISL } 2005 \text { and } 2006 \text { were } \\
\text { grouped together indicating } \\
\text { their genetic resembleness. } \\
\text { The greatest genetic distance } \\
\text { was between GP } 22 / 137 \text { and } \\
\text { GP 22/500 and also the } \\
\text { presence of high number of } \\
\text { sub clusters indicate the } \\
\text { higher genetic variability. } \\
\text { Therefore, genetically } \\
\text { diverse clones can be } \\
\text { obtained from the } 2012 \text { HP } \\
\text { programme (Madushani et } \\
\text { al., 2014) ............... }\end{array}$ \\
\hline 2014 & $\begin{array}{l}\text { (GPS 44-24) } \\
\mathrm{RO} / / \mathrm{CM} / 10- \\
24\end{array}$ & $\begin{array}{l}\text { RRISL2100 } \\
\text { RRISL } 2001 \\
\text { RRISL } 2006 \\
\text { RRIC130 } \\
\text { RRIC131 }\end{array}$ & 165 & Poly bag nursery \\
\hline
\end{tabular}

*-RRI/ECTs- Rubber Research Institute/Estate collaborative trials 


\section{Evaluation of genetic diversity of germplasm \\ Importance of germplasm in order to broaden the Hevea gene pool}

Recently, we have carried out a molecular study to evaluate the genetic diversity of recommended clones. Microsatelite molecular markers were used to determine the genetic diversity of 14 clones which represent all the generations of recommended clones grown in the past few decades; i.e.; early seedling selections of RRIC 100 series, RRISL 200 series and RRISL 2000 series.

According to the result, the Dendrogram clearly showed (Fig. 2) that the most of the recommended clones group together regardless of their generations indicating that they are genetically very similar. Such a narrow genetic base is a danger to the rubber industry. In this analysis the clone RRISL 2005 which had been derived using non Wickham parental materials (germplasm) showed highest genetic distance to the other clones showing the urgent need of the use of the new germplasm material in future Hevea breeding programs.

Being a member country of International Rubber Research Development Board (IRRDB), maintenance, multiplication and evaluation of this non-Wickham germplasm material is a responsibility of a Rubber Research Institute as well as of the government of Sri Lanka.
However, currently, the conservation and utilization of this germplasm have become a problem due to lack of financial and human resources.

Genetic diversity of selected genotypes from year 2008 Hevea (Hevea brasiliensis) hand pollinated progeny using SSR markers

Twenty three Hevea genotypes developed from year 2008 Hand Pollinated progeny, which had used diverse male parents from nonWickham's germplasm (Table 4), were subjected to SSR analyses for genetic diversity with their three mother parents. Eight Hevea SSR markers were used for this study. All these genotypes and mother parents were produced two distinguishable alleles which detected for each of the SSR loci. Three mother clones i.e. RRIC 100, RRIC 121 and PB 28/59 were grouped together by showing their close genetic relatedness probably due to their Wickhams genetic base. Sixteen progeny genotypes deviated from mother parents and nine genotypes out of them showed more than 0.5 genetic distances from all three mother parents indicating a greater level of genetic diversity of the progeny because of the use of non Wickham male parents. These genetically diverse clones from 2008 hand pollination progeny can be added to the Hevea cultivation in the future (Amaratunga $e t$ al., 2013). 


\section{Genetic Diversity analys is of Selected Recommended Rubber (Hevea brasiliensis) Clones Using SSR Markers}

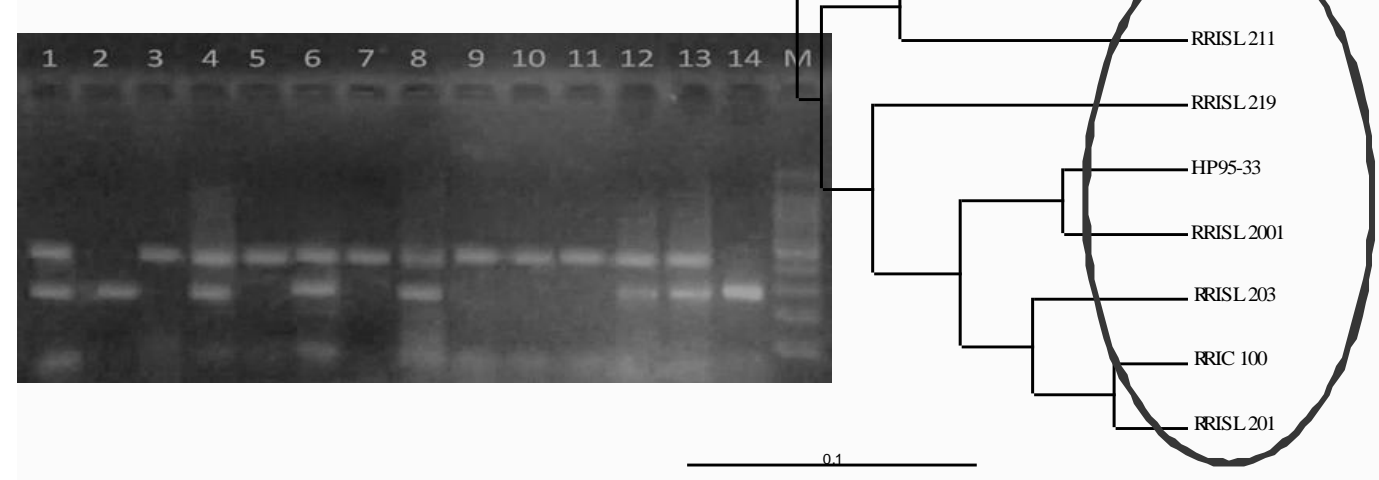

Fig. 2. Molecular analysis of genetic diversity analysis by Microsatellite molecular Markers

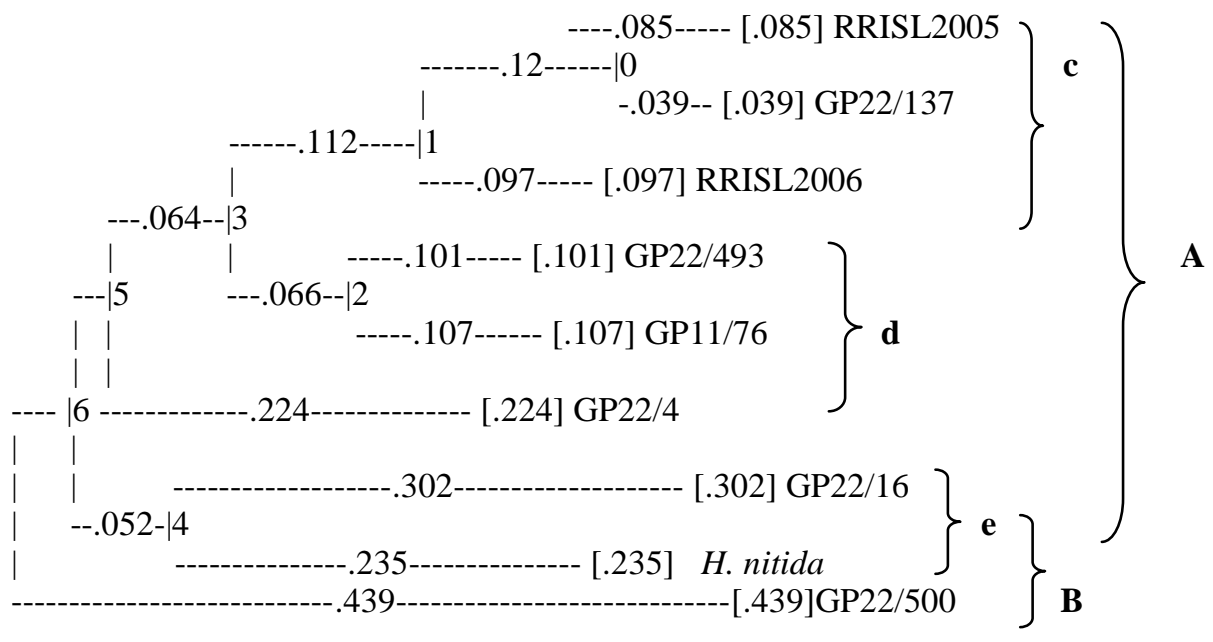

Fig. 3. Genetic diversity analysis of selected parental materials of 2012 HP programme using RAPD markers 
Evaluation of performances of new genotypes developed using the germplasm of Hevea obtained from 1981 IRRDB expedition to the Amazon (RRI/Estate collaborative trial 2011-Yatadola estate)

The IRRDB'81 collection exhibited generally very poor profiles in agronomical characteristics, especially latex productivity. Therefore direct use of this collection for latex production purpose may have limited potential. But progenies of their crosses with Wickhams high yielding clones could produce better clones while expanding the genetic variability.

Ten genotypes selected from 1995 hybridization programme where non Wickham clone GPS 1 was used as a parent, were established at Yatadola estate, Namunukula Plantations PLC. Fifty trees from each genotype were established with control clone RRISL 203. Evaluation of their commercial performances under estate management conditions, was carried out to select genetically diverse clones to be incorporated in RRISL clone recommendation. Performances of all genotypes were well, compared to control clone with respect to the third year girth. Genotypes 95HP29, 95HP41, 95HP19 and 95HP13 obtained higher girth values than control clone RRISL 203 whereas genotype 95HP29 (Fig. 4) showed a significantly higher girth (Table 5). These genotypes were selected for propagation in bud wood nurseries in order to establish a few more RRI/ECT trials. However, all genotypes need to be evaluated further before making a decision on recommendations.

Table 5. Mean girth of first three years and their DMRT ranks of selected genotypes from 1995/1981 hand pollination progenies under estate management conditions (RRI/ECT collaborative trials)

\begin{tabular}{|c|c|c|c|c|c|}
\hline Clone & $\begin{array}{l}1^{\text {st }} \text { year mean } \\
\text { girth }(\mathrm{cm})\end{array}$ & Clone & $\begin{array}{l}2^{\text {nd }} \text { year mean } \\
\text { girth }(\mathrm{cm})\end{array}$ & Clone & $\begin{array}{l}3^{\text {rd }} \text { year mean } \\
\text { girth }(\mathrm{cm})\end{array}$ \\
\hline 95НР19 & $8.49^{\mathrm{a}}$ & 95НР19 & $14.46^{\mathrm{a}}$ & 95НР29 & $25.5^{\mathrm{a}}$ \\
\hline $95 \mathrm{HP} 13$ & $8.21^{\mathrm{a}}$ & RRISL 203 & $14.36^{\mathrm{a}}$ & $95 \mathrm{HP} 41$ & $23.39^{\mathrm{b}}$ \\
\hline 95НР29 & $7.55^{\mathrm{b}}$ & $95 \mathrm{HP} 41$ & $14.28^{\mathrm{a}}$ & 95НР19 & $23.17^{\mathrm{b}}$ \\
\hline 95HP41 & $7.51^{\mathrm{b}}$ & 95HP21 & $14.24^{\mathrm{a}}$ & $95 \mathrm{HP} 13$ & $22.66^{b c}$ \\
\hline 95HP1 & $7.34^{\mathrm{bc}}$ & $95 \mathrm{HP} 23$ & $13.81^{\mathrm{ab}}$ & RRISL203 & $22.26^{\mathrm{bcd}}$ \\
\hline 95HP21 & $7.08^{\mathrm{bc}}$ & $95 \mathrm{HP} 13$ & $13.79^{\mathrm{ab}}$ & 95HP21 & $21.98^{\text {bcde }}$ \\
\hline RRISL203 & $7^{\mathrm{bc}}$ & 95HР29 & $13.66^{\mathrm{ab}}$ & 95HP23 & $21 . .04^{\mathrm{cde}}$ \\
\hline 95HP23 & $6.95^{\mathrm{bc}}$ & 95HP1 & $13.1^{\mathrm{bc}}$ & 95HP1 & $20.47^{\mathrm{de}}$ \\
\hline 95HP33 & $6.81^{\mathrm{dc}}$ & 95HP33 & $12.55^{\mathrm{c}}$ & 95HР33 & $20.22^{\mathrm{e}}$ \\
\hline 95HP55 & $6.27^{\mathrm{d}}$ & 95HP55 & $11.37^{\mathrm{d}}$ & 95HР55 & $16.23^{\mathrm{f}}$ \\
\hline 81HP69 & $6.2^{\mathrm{d}}$ & 81HP69 & $10^{\mathrm{e}}$ & 81HP69 & $14.29^{\mathrm{g}}$ \\
\hline
\end{tabular}




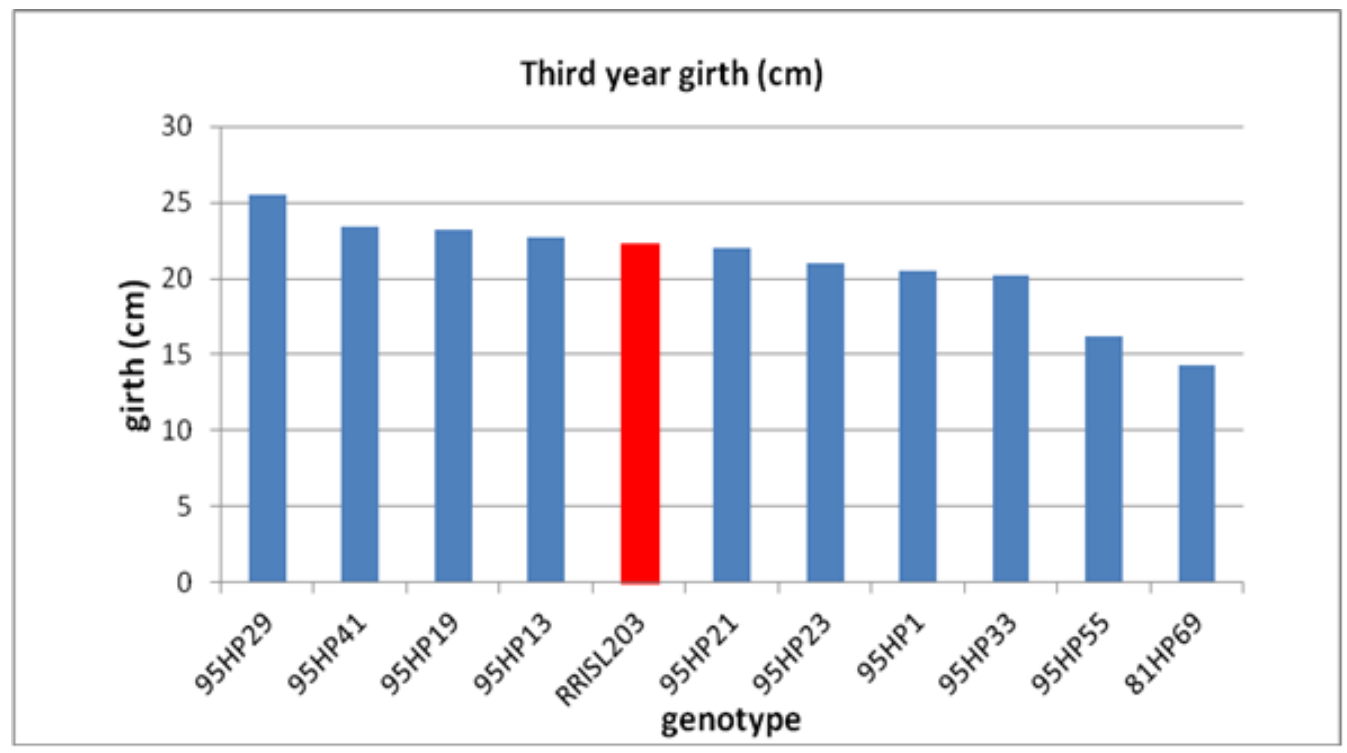

Fig. 4. Third year girth compared with control clone RRISL 203

Current Status of $e x$ - situ collection of germplasm in Sri Lanka

The germplasm collections in Sri Lanka are now nearly 30 years old. Vigorous clones have over grown to the extent of hindering the less vigorous ones. This leads to loss of some of these less vigorous genotypes in the collection. Therefore, it is important to fill the vacancies that occur as a result. Having all the genotypes in one location is also a risk. Hence, the duplication of collection in other locations is also important and it is advisable to duplicate the population at least in two more locations, preferably one in wet area and the other in dry area with normal spacing used as in commercial plantation. This will enable us to do future evaluations of economically important trait as well as the maintenance of material without any loss. Further, maintenance and scientific evaluation of this IRRDB germplasm collection and judicial use of promising genotypes will increase the efficiency of the present breeding programme by providing more genetic variability for the breeder to select upon.

Therefore, the project on Multiplication/Establishment and scientific evaluation of the Hevea germplasm collection was commenced in the year 2014 with the aim of enhancement of productivity through genetic improvement and management of genetic resources of 
Hevea. (Under new development proposal for Annual Budget, 2014);

\section{Specific objectives are:}

- Establishment and maintenance of the 1981 IRRDB germplasm collection obtained from 1981 IRRDB expedition to the Amazon

- Scientific evaluation of the Hevea germplasm collection to classify the genotypes according to genetic parameters and by using molecular marker $\mathrm{s}$ to identify promising genotypes for future breeding programme

- Incorporation of promising genotypes to Hevea breeding programme.

\section{First year: 2014}

Four thousand fifty seven (4057) trees that belong to 1478 number of accessions were selected (Table 6) and pollarded at the height of $4 \frac{1}{2} \mathrm{ft}$ above the ground level to prepare bud woods (Fig. 5). Poly bag nursery was raised with 16,000 plants and ground nursery was established with 1000 plants. Three planting sites Nivitigalakele substation (9.2 ha), Polgahawela substation (2 ha) and Monaragala substation (1ha) were selected and land preparation was done. Scientific evaluation and characterization of accessions were started (Fig. 6) (Withanage 2014).

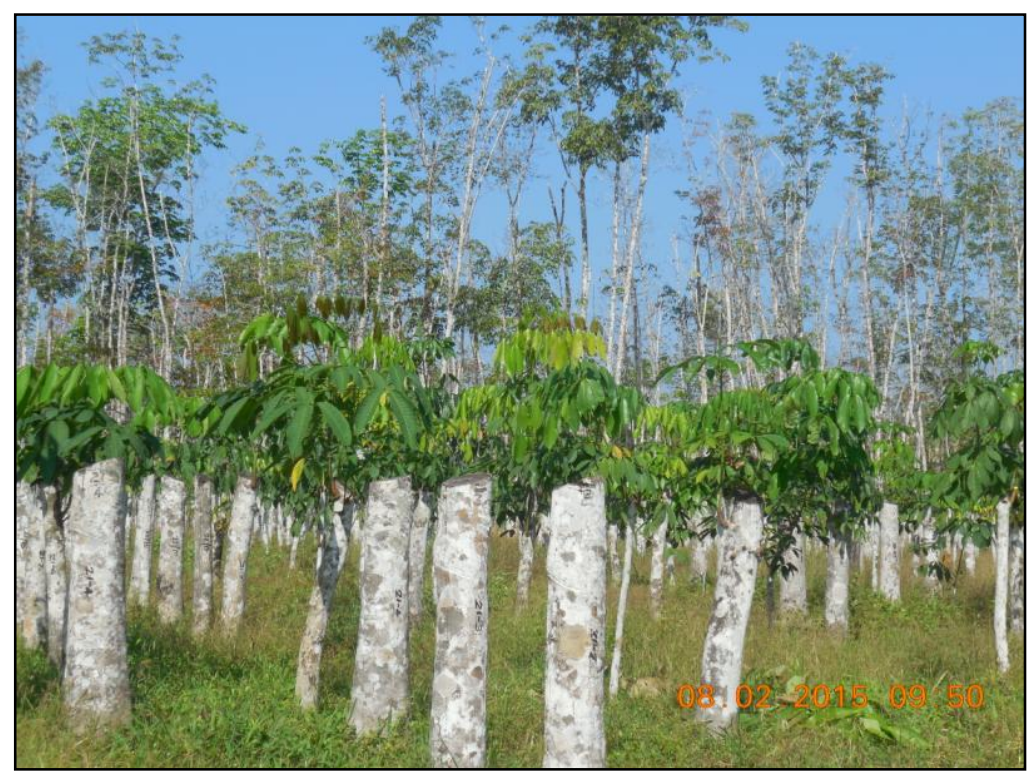

Fig. 5. Preparation of bud wood of selected accessions for multiplication at Neuchatle estate 
Table 6. Selected accessions and their germplasm code prepared to establish in the year 2014- 2015 season

\begin{tabular}{lcc}
\hline Germplasm code & Number of selected accessions & Bed No. \\
\hline $\mathrm{RO} / \mathrm{PB} / 1$ & 103 & 02 \\
$\mathrm{RO} / \mathrm{PB} / 2$ & 210 & 03 \\
$\mathrm{RO} / \mathrm{OP} / 4$ & 118 & 20 \\
$\mathrm{RO} / \mathrm{JP} / 3$ & 209 & 22 \\
$\mathrm{AC} / \mathrm{F} / 5$ & 157 & 21 \\
$\mathrm{AC} / \mathrm{T} / 2$ & 45 & 04 \\
$\mathrm{AC} / \mathrm{T} / 1$ & 91 & 05 \\
$\mathrm{AC} / \mathrm{T} / 3$ & 21 & 06 \\
$\mathrm{AC} / \mathrm{T} / 4$ & 54 & 13 \\
$\mathrm{MT} / \mathrm{C} / 1$ & 40 & 18 \\
$\mathrm{MT} / \mathrm{C} / 10$ & 38 & 17 \\
$\mathrm{MT} / \mathrm{C} / 2$ & 90 & 10 \\
$\mathrm{MT} / \mathrm{C} / 6$ & 54 & 11 \\
$\mathrm{MT} / \mathrm{C} / 5$ & 76 & 12 \\
$\mathrm{MT} / \mathrm{C} / 8$ & 07 & 14 \\
MT/C/9 & 17 & 15 \\
MT/C/3 & 17 & 16 \\
MT/C/4 & 98 & 07 \\
MT/C/7 & 09 & 08 \\
MT/C/11 & 24 & 09 \\
7/02/81 & 20 & 01 \\
Total & 1478 & \\
\hline
\end{tabular}

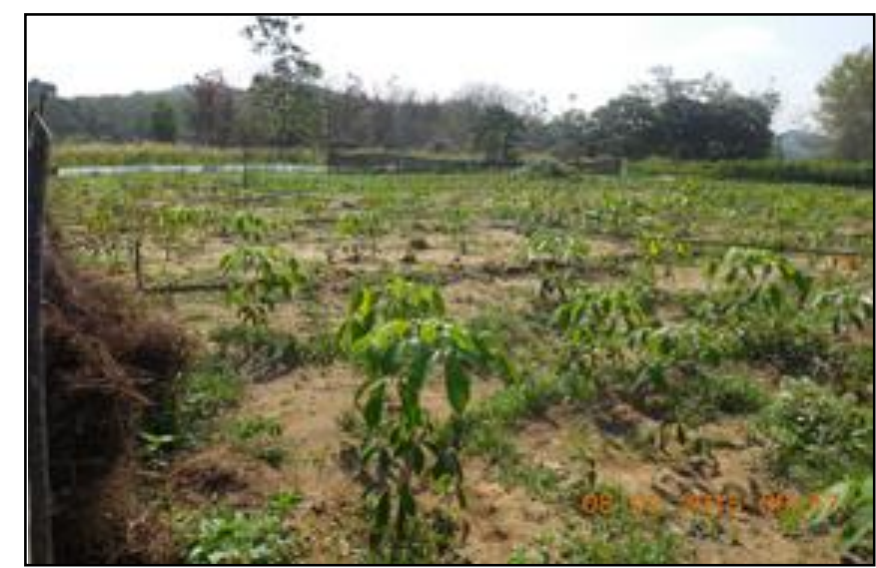

Fig. 6. Establishment of selected accessions for characterization at Neuchatle estate 
However, many germplasm collections in many crops are being lost worldwide. The erosion of the genetic variability of Hevea plantations in all over the world is under a constant threat of sudden out breaks of a native as well as exotic diseases while complicating the situation with changing climate. Therefore, it is important that the potential uses and values of this genetic resources need to be developed to improve and facilitate productive utilization in Hevea breeding in future. Maintenance and conservation of the core collection is also very important.

\section{Acknowledgements}

Authors wish to acknowledge the Namunukula Plantations PLC for granting research project "Evaluation of performances of new genotypes developed using the germplasm collection of Hevea obtained from 1981 IRRDB expedition to the Amazon" caring as a RRI/ECT collaborative trial 2011-Yatadola.

\section{References}

Anon (2012). Rubber sector. Statistical information on plantation crops, Ministry of Plantation Industries. 65171.

Amarathunge, L A R, Withanage, S P and Sumanasinghe, V A (2013). Genetic diversity of selected genotypes from year 2008 hand pollination progeny of Havea brasiliensis using SSR markers. Proceeding of the undergraduate research, Department of Agricultural Biology, University of Peradeniya 4, 6669.

Madushani, H K I, Sumanasinghe, V A and Liyanage, K K (2014). RAPD in assessment of genetic diversity of Hevea breeding population in 2012. Proceedings of Peradeniya University International Research Sessions Sri Lanka, 18, 547.

Kodikara, K S S, Withanage, S P and Attanayake, D P S T G (2011). Genetic diversity of selected recommended rubber (Hevea brasiliensis) using SSR markers". Proceeding of $11^{\text {th }}$ Agricultural Research Symposium, Wayamba University of Sri Lanka, 1620.

Jayasekara, N E M (1989). Annual Review, Rubber Research Institute of Sri Lanka.

Jayasekara, N E M (1991). Annual Review, Rubber Research Institute of Sri Lanka.

Jayasekara, N E M (1992). Annual Review, Rubber Research Institute of Sri Lanka.

Jayasekara, N E M (1993). Annual Review, Rubber Research Institute of Sri Lanka.

Jayasekara, N E M (1994). Annual Review, Rubber Research Institute of Sri Lanka.

Withanage, S P (1989). Annual Review, Rubber Research Institute of Sri Lanka.

Withanage, S P (2014). Annual Review, Rubber Research Institute of Sri Lanka.

Address for correspondence: Dr (Mrs) S P Withanage, Head, Genetics \& Plant Breeding Dept., Rubber Research Institute of Sri Lanka, Nivithigalakele, Matugama, Sri Lanka.

e-mail:pamuditharama@yahoo.com 